\title{
OTOJEN DİŞ KEMİK GREFTİNİN BİYOLOJİK ÖZELLİKLERİ VE KLİNİK KULLANIMI
}

\author{
BIOLOGICAL FEATURES AND CLINICAL USE OF AUTOGENOUS TOOTH BONE \\ GRAFT
}

\author{
Öğr. Gör. Gözde IŞIK ${ }^{*}$ \\ Prof. Dr. Sema ÇINAR BECERİK**
}

\author{
Doç. Dr. Banu ÖZVERİ KOYUNCU* \\ Prof. Dr. Tayfun GÜNBAY*
}

Makale Kodu/Article code: 4191

Makale Gönderilme tarihi: 23.10.2019

Kabul Tarihi: 19.12.2019

DOI: $10.17567 /$ ataunidfd. 661479
Gözde Işık: ORCID ID: 0000-0001-9572-3049

Banu Özveri Koyuncu: ORCID ID: 0000-0002-0074-0055

Sema Çınar Becerik: ORCID ID: 0000-0003-2472-3599

Tayfun Günbay: ORCID ID: 0000-0002-9685-3942

\section{öz}

Kemik dokunun tamiri ve yenilenmesinde, allogreft, ksenogreft ve sentetik kemik greftlerinin eksikliklerinin üstesinden gelebilecek ve otojen kemik greftlerine benzer kemik rejenerasyon kapasitesine sahip yeni materyaller geliştirmek için çalışmalar devam etmektedir. Otojen diş kemik greftleri, fiziksel ve biyolojik yapısı kemik doku ile benzer olan bir materyaldir. Bu greft, inorganik ve organik olmak üzere iki bileşene sahiptir. Organik yapı içerisinde yer alan kemik morfogenetik proteinleri, kollajen ve kollajen olmayan proteinler ile inorganik yapının oluşumunda bir iskelet görevi görür. İnorganik yapının büyük bir yüzdesini oluşturan hidroksiapatit kristalleri dokuya dayanıklıık kazandıır ve organik yapı ile birlikte yeni kemik doku oluşumunu sağlar. Bu derleme, geleneksel kemik greft materyallerine göre daha iyi bir alternatif olarak hizmet edebileceği düşünülen otojen diş kemik greftleri hakkında bilgi sunmaktadır.

Anahtar Kelimeler: Otojen diş kemik grefti; kemik ogmentasyonu; yeni geliştirilen kemik greft materyalleri

\section{ABSTRACT}

The studies focus on new bone grafts which as an alternative of allograft, xenograft and synthetic bone graft and, have a similar bone regeneration capacity with autogenous bone grafts. Autogenous tooth bone grafts are materials whose physical and biological structure is similar that of the bone tissue. This graft has two components, inorganic and organic. Organic structure that includes bone morphogenetic proteins, collagen and non-collagen proteins act as a scaffold for the formation of the inorganic structure. Hydroxyapatite crystals, which make up a large percentage of the inorganic structure, give the tissue durability and provide new bone tissue formation with the organic structure. This review provides knowledge on autogenous tooth bone grafts that may serve as a better alternative to conventional bone graft materials.

Key words: Autogenous tooth bone graft; bone augmentation; novel bone grafting materials

${ }^{*}$ Ege Üniversitesi Diş Hekimliği Fakültesi, Ağız, Diş ve Çene Cerrahisi Anabilim Dalı, İzmir.

${ }^{* *}$ Ege Üniversitesi Diș Hekimliği Fakültesi, Periodontoloji Anabilim Dalı, İzmir.

Kaynakça Bilgisi: Işıı G, Özveri Koyuncu B, Çınar Becerik S, Günbay T. Otojen diş kemik greftinin biyolojik özellikleri ve klinik kullanımı. Atatürk Üniv Diş Hek Fak Derg 2020; 30: 659-70

Citation Information: Işik G, Ozveri Koyuncu B, Cinar Becerik S, Gunbay T. Biological features and clinical use of autogenous tooth bone graft. J Dent Fac Atatürk Uni 2020; 30: 659-70.

\section{GİRIŞ}

Kemik greftleri, kemik doku tamiri ve yenilenmesini sağlamak amacıyla diş hekimliğinde sıklıkla kullanılmaktadır. ${ }^{1-3} \mathrm{Bu}$ tamir ve yenilenme sürecinde osteojenik, osteoindüktif veya osteokondüktif özellikler kemik greftinin başarısını tanımlar. ${ }^{4}$

Osteoindüksiyon, alıcı sahada mezenkimal kök hücrelerin osteoblastlara farklılaşmasıyla sağlanan bir süreçtir ve kemik morfojenik proteinleri ， büyüme faktörleri ve sitokinler gibi yeni kemik yapımını uyaran hücreler aracılığıyla gerçekleşir . 4-6 Osteokondüksiyon, kemik greftinin osteoblast hücreleri , vaskülarizasyon ve hücre göçü için üç boyutlu iskelet sağlanması olarak tanımlanır. ${ }^{3}$ Bu biyolojik yapı, greftin alıcı saha ile olan osseointegrasyon hızını belirler. ${ }^{4-6}$ Osteogenezis, greft içerisindeki hücreler tarafından yeni kemik sentezidir . Osteojenik özellikler , öncül hücreler ve osteoblastlar 
tarafından oluşturulmaktadır. Öncül hücreler olarak tanımlanan mezenkimal kök hücreler, osteoblastlara farklılaşarak yeni kemik yapımını uyarır. Greftlerin osteojenik, osteoindüktif ve osteokondüktif özelliklerden en az birine sahip olması gerekmektedir. ${ }^{5}$

Kemik greftleri orjinine göre aşağıdaki şekilde sınıflandırılmaktadır. ${ }^{5-7}$

Otojen greftler; Aynı bireyde, bir bölgeden (verici saha) başka bir bölgeye (alıcı saha) nakledilen greftlerdir.

İzojen greftler; Alıcı canlı ile aynı genetik yapıya sahip canlılardan alınan dokulardır.

Allogreftler; Aynı türden fakat genetik olarak farkı iki birey arasında yapılan doku transferidir.

Ksenojenik greftler (ksenogreftler); Bir türden farklı bir türe yapılan doku transferidir.

Alloplastik (sentetik) greftler; Canlı olmayan materyallerden üretilen greftlerdir.

Bireyin kendisinden elde edilen otojen kemik greftleri, klinik kullanımda sıklıkla tercih edilmektedir. ${ }^{7}$ Osteojenik, osteoindüktif ve osteokondüktif özellikleriyle yeni kemik yapımını sağlamaktadır. Bu greft, immün reaksiyon oluşturmadan kemik iyileşme mekanizmasını uyarır. ${ }^{8}$ Bununla birlikte, otojen kemik greftlerinin yeterli oranda ve boyutta elde edilememesi, cerrahi ve donör saha komplikasyonları bu greftin kullanımını sınırlandırmaktadır. ${ }^{7-9}$

Farklı greftlerin klinik sonuçları değerlendirildiğinde, otojen kemik grefti halen 'altın standart' olarak kabul edilmektedir. ${ }^{1,2,5,7,8,10}$ Bu sonuçlara dayanarak, allogreft, ksenogreft ve sentetik kemik greftlerinin eksikliklerinin üstesinden gelebilecek, otojen kemiklere benzer kemik rejenerasyon kapasitesine sahip yeni malzemeler geliştirmek ve değerlendirmek için çalışmalar devam etmektedir.

\section{otojen Diş Kemik Grefti}

Otojen diş kemik grefti (ODKG) dentin dokusundan oluşmaktadır. Dentin dokusu, dişin hacminin büyük bir kısmını oluşturan gözenekli bir yapıdır. Bu doku, fizyolojik ve anatomik olarak karmaşık özelliklere sahiptir ve kemik dokusuyla birçok yapısal benzerliği paylaşır. Alveoler kemik dokusunun inorganik, organik ve su içeriği sırasıyla $\% 65, \% 25$ ve $\% 10^{\prime}$ 'dur ve benzer olarak, dentin dokusu, \% 70-75 inorganik, $\% 20$ organik ve $\% 10$ sudan oluşmaktadır. ${ }^{11-14}$ Kemik dokusunda olduğu gibi dentin dokusu da, mekanik ve biyolojik desteklik sağlar: 1) üst üste binen katmanlar halinde mine dokusunun altında kuvvet dağılımı sağlayarak çatlak veya kırık oluşumunu önler, 2) vaskülarizasyonu sağlayan pulpa dokusu için biyolojik koruma sağlar. ${ }^{13}$
Kemik ve dentin gelişiminde hücresel aktivite benzerlik göstermektedir.

Bu biyolojk benzerliklerden ilki, dentin analoglarının kemik dokuya olan benzerliğidir. Kemik dokuda, lakunalar içinde yer alan osteositler gibi tübüller içinde osteoblast/odontoblast benzeri hücreler yer almaktadır. Osteodentin adı verilen bu yapı, insanlarda tamir dentininde gözlenmektedir. ${ }^{15}$

İkincil bir biyolojik benzerlik olarak dentin oluşumunda gözlenen matriks salınımı sayılabilir. Dentin oluşumu ve şekillenmesinde odontoblast hücreleri görev alır. ${ }^{16}$ Dentin matriksinin salgılanmasına yardımcı olurlar. Bu matriks, kıkırdak ve kemik dokuyla benzer olarak sırasıyla mineral birikimi ve fibrinogenezizde rol oynar. ${ }^{17}$

Bir diğer biyolojik benzerlik ise tübüller gelişim ve mineralizasyon fazıdır. Dentin gelişimi esnasında, diş kök gelişimi tamamlanmadan ilk olarak circumpulpal dentin oluşur. Mineralize yapıda olmayan bu dentin tabakası predentin olarak adlandırılır. ${ }^{18}$ Diş dokusunun gelişimi ile birlikte, predentin içinde yer alan odontoblastlar kutupsal olarak polarize hale geldiklerinde ortodentini oluşturur. Ortodentin, içerisinde, predentin içinden geçen ve dentin-mine bağlantısına kadar uzanan dentin tübülleri yer almaktadır. ${ }^{19} \mathrm{Bu}$ nedenle, tübüler dentin olarak da adlandırımaktadır ve içerisinde eş zamanlı olarak gelişen ancak yapısal ve içerik olarak farklılık gösteren iki farklı tübüller yapı bulunmaktadır: intertübüler dentin ve peritübüler dentin. ${ }^{20}$ Peritübüler dentin, tübüler lümenin çevresinde gözlenen mineralize bir yapıdır. Farklı olarak, intertübüler dentin, dentin oluşumunda rol alan organik içeriği (tip 1 kollajen) ile tübüler dentinin büyük bir kısmını oluşturur. İntertübüler dentin, predentin ile dentin oluşum ve mineralizasyonu esnasında meydana gelen değişikliklerin bir sonucudur ve intertübüler dentin oluşumu, dentin matriks mineralizasyonunun üç-aşamalı yapım modelini ortaya koyar. Anatomik olarak bu aşamalar sırasıyla; hücresel stratum, predentin ve mineralize dentin dokusunun oluşumudur. Bu model, kemik oluşum modeli ile benzerlik gösterir: osteoblast/kemik hücre tabakası, osteoid ve kemik dokusu. ${ }^{18}$

Bu benzerliklerin yanı sıra kemik dokudan farklı olarak, dentin vaskülarize bir yapı göstermez ve dentin dokusu inorganik ve organik yapı olmak üzere iki temel bileşenden oluşur. ${ }^{14}$

\section{Inorganik Yapı}

Dentin dokusunun ana bileşeni olarak inorganik yapı, dört tip kalsiyum fosfat minerali içerir. Bu mineraller sırasıyla, hidroksiapatit (HA), $\beta$-trikalsiyum 
fosfat ( $\beta$-TKF), amorf kalsiyum fosfat (AKF) ve oktakalsiyum sodyum fosfattır (OKSF). ${ }^{21}$ Dentin inorganik bileşeni, dentin kollajeninin bozulmasını teşvik eder ve dentin matriksinin öngörülebilir ve kontrollü biyolojik bozunmasına yol açar. ${ }^{22}$ Bu nedenle, inorganik yapının oluşumunda kollajen biyo-mineralizasyonu rol oynar ve dentin tübüllerinin yoğunluğu ve dağılımı inorganik bileşenlerin miktarı üzerinde belirleyicidir. ${ }^{9,14,18}$

\section{Hidroksiapatit}

HA, kimyasal yapısında köşelerinde hidroksil $\left(\mathrm{OH}^{-}\right)$iyonlarının yer aldığı ve kalsiyum $\left(\mathrm{Ca}^{+2}\right)$ iyonlarına sahip trigonal prizma ve oktahedra yapısına bağlı izole fosfattetrahidrat $\left(\mathrm{PO}_{4}^{-3}\right)$ içeren altıgen bir yapıya sahiptir. ${ }^{21} \mathrm{HA}$ kristalleri eser miktarda $\mathrm{Cl}, \mathrm{Mg}$, $\mathrm{Na}, \mathrm{Cu}, \mathrm{K}, \mathrm{Fe}, \mathrm{Sr}$ elementlerini içerir ve yüksek oranda karbonat iyonlarından oluşur. Bu iyonlar, HA içinde düzensiz yapıda bulunur. ${ }^{23}$ Karbonat iyonları, $\mathrm{OH}^{-}$iyonlarının yerine geçerek Tip A karbonat $\mathrm{HA}(\mathrm{CHA})$ ve $\mathrm{PO}_{4}{ }^{3}$ iyonlarının yerine geçerek Tip B CHA oluşturur. CI iyonları ise, kristal ve kristal olmayan yapı arasındaki yoğunluk farkını verir. ${ }^{24}$

HA sentezinde, küçük integrin bağlayıcı ligand $\mathrm{N}$-bağlı glikoproteinler (SIBLING) ailesindeki asidik, kollajen olmayan proteinler iki temel görev üstlenir. Bunlar sırasıyla; amorf fazda kalsiyum fosfatın stabilize edilmesi ve kapiller kuvvet veya ozmotik düzenleyici mekanizmalar üzerinden kollajen fibrillerin intermoleküller alana ve amorf minerallerin fibriller arası yapıya penetrasyonudur. Böylelikle, HA nanokristallerinin çekirdekleşmesi kollajen fibriller arasında başlar. ${ }^{25} \mathrm{Bu}$ kristal yapı büyüyerek intermoleküller boşluklar arasına uzanır ve intrafibriller mineral olarak bilinen yapıyı oluşturması sağlanır. Birbirini takip eden fazlar ile amorf mineraller, daha kristalize ve stabil bir HA morfolojisi oluşturur. Bu iyi yönetilen biyo-mineralizasyon işleminin bir sonucu olarak, HA mineral fazı, dentin dokusunun birincil bileşeni haline gelir. ${ }^{26} \mathrm{Bu}$ dokunun, hacimce yaklaşık \% 50, ağırlıkça \% 65 düzensiz HA nanokristallerinden $(\sim 100 \times 30 \times 4$ nanometre $(\mathrm{nm}))$ oluşur. ${ }^{27}$ Bunlar, kollajen fibrillerinin içinde (intrafibriller) veya fibrillerin arasında (ekstra veya interfibriller) bulunur. ${ }^{28}$

HA minerali, dentin doku yenilenmesi ve tamirinde üç boyutlu bir iskelet görevi görür. Bu yapısı ile osteokondüksiyon sağlayarak sitokin ve fibronektin gibi doğal adezivlere bağlanır ve tamir sürecini uyarır. ${ }^{21-25}$

\section{Organik Yapı}

Organik yapıyı, dentin ekstrasellüler matriksi oluşturur. Dentin organik matriksini odontoblastlar tarafindan sentezlenen kollajen ve kollajen olmayan proteinler (Proteoglikan (PG) ve glikozaminoglikanlar
(GAG)) oluşturur. ${ }^{13}$ Bu matriks, HA bağlayıcı proteinler ve matriks içindeki endojen büyüme faktörlerinin salınması için önemli olan nano boyuttaki dentin tübüllerini içerir. ${ }^{18-20}$

Yapısal proteinler olarak ekstrasellüler matriks molekülleri, dentin oluşumuna ve mineralleşmesine katılır. ${ }^{13}$ Uyarıı veya inhibitör olarak görev yapabilirler. $\mathrm{Bu}$ moleküller üç temel özelliğe sahiptir: 1) hücre yüzey reseptörleri ve integrinler ile etkileşime girerler, 2) büyüme faktörlerini ve proteaz aktivitesini modüle ederler, 3) hücre sinyallerinin oluşması ve hücreler arası bağlantıda görev alıılar. ${ }^{29,30}$

Organik matriksin yaklaşık \% 90'ı tip I kollajendir ve eser miktarda tip III ve $V$ kollajende matriks içinde yer alır. ${ }^{31}$ Geri kalan \% $10^{\prime}$ luk matriks, glikoproteinler, kollajen olmayan proteinler, polimer, yağ, sitrat ve laktat bileşenlerinden oluşmaktadır. ${ }^{32}$ Kemik morfogenetik proteinleri (KMP), kollajen ve kollajen olmayan proteinler, dentin dokusunun mineralizasyonunda rol oynar ve organize mineral faz birikimi için bir iskelet görevi görür. ${ }^{33-37}$

\section{Dentin-Kemik Morfogenetik Proteinleri}

Dentin-KMP'leri iki farklı gen tarafından kodlanan osteojenik proteinler olarak adlandırımaktadır. Dentin dokusundan salınan bu doğal moleküller, osteoindüktif proteinler gibi davranır ve kemik oluşumunu sağlar. Bunun için, KMP'ler mezenkimal kök hücrelerin kondrositlere farklılaşmasını teşvik eder. ${ }^{34,35}$

Dentin-KMP-1, benzer bir yapıyı paylaşan ve fonksiyonel roller oynayan küçük bir hücre dışı metalloproteinaz ailesine aittir. KMP-1, normal dentin mineralizasyonu için gerekli olan kollajen ve kollajen olmayan proteinler arasında dengeyi sağlar ve dentin doku tamirinde, osteodentin ve tübüler reparatif dentin for masyonunu uyarır. ${ }^{34}$ Bu proteinaz, prokollajen öncüleri için C-proteinaz enzimini salgılayarak kollajen fibrillerin sentezini arttırrr. ${ }^{38}$

Bununla birlikte dentin yapımı ve mineralizasyonunda önemli rol oynayan dentin matriks protein-1 (DMP-1) ve dentin sialoprotein (DSP) gibi kollajen olmayan proteinlerin yapımına katıtır. ${ }^{39} \mathrm{Bu}$ proteinazın uzaklaştırıması, homeostatik dengeyi bozarak anormal kollajen birikimlerine yol açar ve dentin biyo-mineralizasyonu için önemli olan kollajen olmayan proteinlerde azalmaya neden olur. ${ }^{40,41}$

Dentin matriksi ayn zamanda rekombinant insan kemik morfogenetik protein-2 (KMP-2) için potansiyel bir taşıııc olarak kabul edilmektedir. ${ }^{35-37} \mathrm{KMP}-2$, transforme edici büyüme faktörü- $\beta$ (TEBF- $\beta$ ) süper ailesine ait otokrin bir proteindir. ${ }^{35}$ Dentin formasyonunda etkili olan odontoblastların, salgılanmasını, 
çoğalmasını ve farklılaşmasını doğrudan etkileyen KMP-2 proteini, odontoblastlar tarafından üretilir ve salgılanır. ${ }^{36}$ Bununla birlikte üçüncül dentin oluşumu ve mineralizasyonunda etkilidir. ${ }^{37}$

\section{Tip I Kollajen}

Tip I kollajen, iki adet alfa 1 ve 1 adet alfa 2 zincirinin birleşmesinden meydana gelir. ${ }^{31}$ Predentinde, odontoblastlar, kollajen fibrilasyonunda yer alan bazı PG'larla (dekorin, biglikan, lümikan, fibromodülin) birlikte doğal tip I kollajen salgılanmasından sorumludur. ${ }^{42}$

Sentezlenmesinde, ilk olarak, odontoblast hücre gövdelerinde prokollajen fibrilleri sentezlenir ve bu fibriller pro-alfa 1 ve pro-alfa 2 zincirlerinde prolin ve hidroksiprolin içerir. ${ }^{43}$ Ardından, uzayan ve lateral yönde kümeleşmeye başlayan fibrillerin çapları artar ve bu dinamik süreçte, yeni sentezlenen kollajen, predentin içinde göç eder. ${ }^{44}$ Olgunlaşma safhasında ise kollajen fibriller arasında çapraz bağlar oluşur ve fibriller yapı stabilite kazanır. Bu kollajen fibriller, 80100 nm'lik bir çapa sahiptir ve düzenli bir dağılım gösterirler. ${ }^{45}$

Kollajen fibriller, kollajen olmayan proteinlerin aksine doğrudan mineralizasyona katılmaz ancak, oluşturduğu düzenli iskelet bir yapı ile matriks proteinleri ile birleşir. ${ }^{46}$ Dentin kollajeni, üstün hücre yapışma kapasitesine sahiptir ve mükemmel doku uyumluluğu, absorbsiyon ve zayıf antijenik özelliğe sahiptir. ${ }^{44,47,48}$ Ek olarak, kollajen fibrillerin oluşumunda yer alan Cproteinaz, doku yenilenmesinde etkili KMP-1 ile yapısal olarak benzerlik taşımaktadır. ${ }^{37}$

\section{Kollajen Olmayan Proteinler}

Kollajen olmayan proteinler, fosfoprotein, sialoprotein, glikoprotein, PG, osteopontin, osteokalsin, osteriks, DMP-1 ve Runx2 (Cbfa1)'den oluşur. ${ }^{49}$ Kollajen olmayan proteinler, dentin matriksinin \% 5 'inden azını oluşturur ve bununla birlikte, birçok yapısal ve mekanik fonksiyonlara sahiptirler. ${ }^{50}$

SIBLING ailesi, DSP, DMP-1, kemik sialoprotein $(\mathrm{KSP})$, osteopontin ve matriks ekstrasellüler fosfoglikoprotein (MEFG) içerir. ${ }^{51} \mathrm{Bu}$ glikoproteinler, fosforile edilmiş serin ve treonin ile birlikte dentin biyo-mineralizasyonunun düzenlenmesinde yaygın olarak yer alır. $^{52}$

Interfibriller yapı içinde yer alan SIBLING ailesinin kollajen olmayan proteinleri, strese maruz kaldıklarında kollajen fibrillerden farklı olarak kırılma göstermezler. Stres esnasında oluşan mekanik enerji ile bu proteinlerin intermoleküler bağları bozulur ve sarmal yapı açılım gösterir. Bu özelliği ile kollajen olmayan proteinler, doku içerisindeki yapıştırıcı madde olarak da tanımlanmaktadır. ${ }^{53}$

DSP, hedef gen ekspresyonunun düzenlenmesi yoluyla dental mezenkimal hücrelerin farkılaşmasını sağlar. ${ }^{40}$ Ek olarak, DSP gen ekspresyonunu ve protein fosforilasyonunu düzenler ve böylece, dentin oluşumuna katıır. DSP, aynı zamanda, dentin biyo-mineralizasyonunda görev alır. ${ }^{54}$

DSP'nin bir bölünme ürünü olan dentin fosfoproteini (DFP), interfibriller ve intertübüler dentin mineralizasyonuna, mineral kristallerinin ilk oluşumuna ve mineral olgunlaşmasına katkıda bulunur. ${ }^{55}$ Asit bakımından zengin alanlar veya fosfoproteinler, çekirdek, inhibitör, bağlayıcı molekül, büyüme düzenleyici yapı veya mineral birikimi için substrat olarak görev yapar. $^{14}$

DMP-1 bir dentin matriks fosfoproteinidir. DMP1 hem çekirdeği hedef alan bir transkripsiyon faktörü hem de mineralizasyonu başlatan hücre dışı bir matriks proteini olarak iki fonksiyona sahiptir. ${ }^{56} \mathrm{Bu}$ fosfoproteinin, kalsiyum bağlama kapasitesi yüksektir ve kollajene yüksek afinite gösterir. ${ }^{57}$ DMP-1 ve tip I kollajen arasındaki iş birliğine dayalı etkileşimler apatit çekirdeklenmesini ve mineral birikimini başlatabilir. Bu nedenle, kristal çekirdeklenme ve büyümenin düzenlenmesinden sorumludur. ${ }^{58}$ Bununla birlikte, dentin dokusu strese maruz kaldığında, oluşan mekanik enerjiyi dağıtarak doku direncini arttırır. ${ }^{59}$

Bu matriks fosfoproteini, mezenkimal hücrelerin odontoblastlara farklılaşmasını uyarır ve mineralizasyonu düzenler. Bu özelliği ile, kemik matriks proteinlerinin bir üyesi gibi davranış gösterir. ${ }^{33}$

Runx2, kemik ve diş gelişimi için temel bir transkripsiyon faktörü görevi görür. DSP de dahil olmak üzere mineralizasyon ile ilişkili genlerin ekspresyonunu kontrol eder. ${ }^{35}$

\section{Proteoglikanlar}

PG mineralize ve mineralize olmayan bağ dokusunun temel biyomolekülleridir. ${ }^{60-62}$ GAG yan zincirine kovalent olarak bağlanmış bir protein çekirdeğinden oluşurlar ve dentin matriksinin \% 3'ünden daha azını temsil ederler. ${ }^{61}$ Yük taşıyan dokularda PG'lar, dokuya daha yüksek hidrofiliklik sağlayan elektrostatik etkileşim bölgeleri sağlayarak ozmotik basınca katkıda bulunurlar. Böylelikle dentin dokusunun dayanıklılı̆ı arttırılmış olur. Bunun için, PG, su moleküllerini bağlar, düzenler ve negatif yüklü molekülleri iter. Oluşan yüksek hidrofiliklik, spesifik çekirdek proteinlerine kovalent olarak bağlanmış bir veya daha fazla GAG ile uyarılır. Dentin dokusunda, kondroitin-4-sülfat (C4S) / kondroitin-6-sülfattan (C6S) zengin dekorin ve biglikan en baskın GAG ve PG'lardır. ${ }^{52}$ 
PG, dentin dokusunun biyolojik özelliklerini düzenlemesinin yanı sıra üç boyutlu yapısını da oluşturur. ${ }^{60}$ Organ ve doku mekanizması ile yaşlanmasında belirgin bir role sahiptir ve bu nedenle, matür dentin dokusunda düşük yoğunlukta yer alırlar. ${ }^{61}$ PG, hem mineralize hem de yumuşak dokulardaki kollajenler arasında interfibriller supramoleküler köprüler oluşturur. ${ }^{62}$

PG'lar ve GAG'lar, intertübüler dentin içinde, su emilimini düzenlerler. Bu yapı, doku mekanik stres altındayken gözenekli kollajen ağındaki sıvı akışının olası düzenlenmesi ile bağlantılıdır ve aynı zamanda dentinin elastik davranışı olarak tanımlanır. Negatif yüklü GAG'larda meydana gelen elektrostatik etkileşimler, çözeltideki PG molekülünün genişlemesine öncülük eder. Bu durum, kollajen-PG ağında artan hidrostatik basınca katkıda bulunur ve dokunun dayanıklıı̆ıının artmasını sağlar. ${ }^{63}$

Yapı bütünlüğünün korunmasında bir diğer faktör olarak, PG'lar ve GAG'lar, ekstrasellüler matriks stabilitesinde görevli mineralize dokuların organik birleşimini birbirine bağlar. Ek olarak, PG ve diğer kollajen olmayan proteinler, dentindeki translasyon sonrası organizasyonda ve kollajen fibrillerinin stabilitesinde yardımcı olmaktadır. ${ }^{52,62}$

\section{Otojen Diş Kemik Grefti Eldesi}

1993 yılında, insan dişlerinin kemik grefti olarak kullanıldığı deneysel çalışmalara başlanmıştır. ${ }^{64-69} 2008$ yılında, ODKG geliş̧irilmiştir. İlk klinik çalışma olarak, Kim ve arkadaşları ${ }^{9}$ diş çekimi sonrası implant cerrahisi planlanan hastalarda, kemik ogmentasyonunda ODKG kullanmışlardır. Toplamda 6 hastanın yer aldığı çalışmada, alveoler kemik ogmentasyonu dental implant cerrahisi ile aynı anda uygulanmıştır. Beş aylık takip sonrası, ogmentasyon sahasından kemik örneği alınmıştır. Histolojik incelemede, alınan kemik örneklerinde $H A$ içeriğinin yüksek olduğunu ve az miktarda $\beta$ TKF, AKF ve OKSF bulunduğunu rapor etmişlerdir. Araştırmacılar, ODKG'nin osteoindüksiyon ve osteokondüksiyon ile kademeli olarak rezorpsiyona uğrayarak yerini mükemmel kalitede yeni kemik dokusuna bıraktığını bildirmişlerdir.

Bu greftin eldesinde temel olarak, periodontal, endodontik veya cerrahi olarak çekim endikasyonu konmuş otojen dişler, klinik kullanım öncesi tüm yabancı maddelerden arındırıır. ${ }^{9}$ Dekontaminasyonu sağlamak ve yumuşak dokuların uzaklaştırılması için çekilmiş dişler \% 4 hidrojen peroksit ve \% 70 etanol ile 10 dakika süresince yıkanır. Bu işlemin ardından, diş yüzeyinden mine ve sement dokusu uzaklaştırılarak dentin dokusu korunur. ${ }^{64,66,69}$ Dentin dokusu, blok şeklinde kullanılabildiği gibi otomatik programlı ve farklı boyutlarda greft eldesine izin veren cihazlar veya manuel olarak el aletleri ile toz haline getirilebilir. ${ }^{64-69}$ Ike ve Urist $^{33}$ tüm bu liyofilizasyon ve sterilizasyon işlemlerinden geçirilmesine rağmen dentin dokusunun organik yapısının korunduğunu ve elde edilen dentin dokusunun, ODKG'nin temel içeriğini oluşturduğunu belirtmişlerdir.

\section{Otojen Diş Kemik Grefti ile in-vivo Calışmalar}

ODKG'nin kullanıldığı in-vivo çalışmalar Tablo 1 ve Tablo 2'de özetlenmiştir.

\section{Hayvan Calışmaları}

Kim ve arkadaşları $^{70}$ yaptıkları çalışmada, ODKG'nin osteoindüktif özelliğini ve organik doku içeriğini değerlendirmişlerdir. ODKG, ortodontik tedavi amaçı veya aşırı kron harabiyeti nedeniyle çekim endikasyonu konmuş insan dişlerinden elde edilmiştir. Bu greft, 15 atimik farenin dorsal deri altı kas dokusuna yerleştirilmiştir. Histolojik inceleme için örnekler 2, 5 ve 8 . haftada alınmıştır. Organik içeriğin araştırılması için Bradford deneyi, sodyum dodesil sülfat poliakrilamid gradyan jeli ve western blot analizi uygulanmıştır. Araştırmacılar, yeni kemik oluşumunun 2. Haftada başladığını ve hücre analizinde, kollajen olmayan proteinlere rastlandığını rapor etmişlerdir. Bu çalışmanın sonuçlarına göre, ODKG, kollajen olmayan protein içeriği ile osteokondüktif ve osteoindüktif özelliklere sahip, basit ve güvenilir bir greft olarak tanımlanmıştır.

On iki aylık beyaz tavşanların denek olarak kullanıldığı bir çalışmada, dentin dokusunun KMP içeriği değerlendirilmiştir. Tavşanların mandibular molar dişlerinin çekimini takiben dentin dokusu elde edilmiş ve uzun kemiklerinden kemik doku örneği alınmıştır. Yara iyileşmesini takiben 14. günde ise çekim bölgelerinden yumuşak doku örneği alınmıştır. Araştırmacılar, KMP'nin, kemik ve dentin matriksi ile yara bölgesinde gözlendiğini ve yeni kemik doku oluşumunda etkili olduğunu bildirmişlerdir. ${ }^{71}$

Çekim soketlerinin değerlendirildiği bir diğer çalışmada, 6 Beagle köpeğinin alt çene premolar ve molar dişleri çift taraflı olarak çekilmiş ve ODKG olarak kullanılmak üzere toz haline getirilmiştir. Çalışmada, 3 . ve 4. premolarlar ve 1 . molar dişlerin çekim soketi greftlenmiş ve 2 . premolar diş çekim soketi kontrol grubu olarak bırakılmıştır. 30 ve 90 . günlerde alınan kemik örnekleri ile histolojik değerlendirme yapılmıştır. Araştırmacılar, test grubunda kemik yapımının daha yüksek olduğunu rapor etmişlerdir. Bu nedenle, ODKG'nin, soket korumada etkili bir biyomateryal olduğu bildirilmiştir. ${ }^{72}$ 
Tablo 1. ODKG kullanılan hayvan çalışmalarının özeti

\begin{tabular}{|c|c|c|c|c|c|c|c|}
\hline Sayı & $\begin{array}{l}\text { Yazar Adı ve } \\
\text { Yayınlandığı YII }\end{array}$ & $\begin{array}{l}\text { Örneklem } \\
\text { Büyüklüğü }\end{array}$ & Uygulama Bölgesi & $\begin{array}{l}\text { Kontrol } \\
\text { grubu }\end{array}$ & $\begin{array}{l}\text { Örnek } \\
\text { alımı }\end{array}$ & Analiz Materyali & Çalışma Sonuçları \\
\hline 1 & $\begin{array}{l}\text { Kim ve ark., } \\
2013\end{array}$ & $\begin{array}{l}15 \text { Adet Atimik } \\
\text { Fare }\end{array}$ & $\begin{array}{l}\text { Deri altı kas } \\
\text { dokusu }\end{array}$ & - & $\begin{array}{l}\text { 2., } 5 . \text { ve } \\
\text { 8. hafta }\end{array}$ & $\begin{array}{l}\text { Bradford deneyi, sodyum dodesil sülffat, } \\
\text { poliakrilamid gradyan jeli ve western blot } \\
\text { analizi }\end{array}$ & $\begin{array}{l}\text { 2.haftada yeni kemik oluşumu, } \\
\text { kollajen olmayan proteinlerin varlığı }\end{array}$ \\
\hline 3 & $\begin{array}{l}\text { Calvo-Guirado ve } \\
\text { ark., }{ }^{72} 2018\end{array}$ & $\begin{array}{l}6 \text { Adet Beagle } \\
\text { Köpeği }\end{array}$ & $\begin{array}{l}\text { Premolar ve molar } \\
\text { dişlerin çekim } \\
\text { soketi }\end{array}$ & $\begin{array}{l}\text { Boş çekim } \\
\text { soketi }\end{array}$ & $\begin{array}{l}\text { 30. ve } \\
\text { 90. gün }\end{array}$ & Kemik örneği & $\begin{array}{l}\text { Daha yüksek oranda kemik doku } \\
\text { tamiri }\end{array}$ \\
\hline 5 & $\begin{array}{l}\text { Lee ve ark. }{ }^{14} \\
2013\end{array}$ & $\begin{array}{l}\text { 18-24 Ayllk 5 } \\
\text { Adet Kücük } \\
\text { Domuz }\end{array}$ & Maksiller Sinüs & $\begin{array}{l}\text { Sentetik } \\
\text { kemik grefti }\end{array}$ & 12. hafta & Kemik örneği & $\begin{array}{l}\text { Her iki grupta da benzer oranda yeni } \\
\text { kemik yapımı }\end{array}$ \\
\hline
\end{tabular}

Tablo 2. ODKG kullanılan klinik çalışmaların özeti

\begin{tabular}{|c|c|c|c|c|c|c|c|c|c|}
\hline Sayı & $\begin{array}{l}\text { Yazar Adı ve } \\
\text { Yayınlandığı } \\
\text { Yıl }\end{array}$ & $\begin{array}{l}\text { Örneklem } \\
\text { Büyüklüğü }\end{array}$ & Uygulama Yöntemi & $\begin{array}{c}\text { Uygulama } \\
\text { Şekli }\end{array}$ & Kontrol grubu & $\begin{array}{c}\text { Örnek } \\
\text { alımı }\end{array}$ & $\begin{array}{l}\text { Takip } \\
\text { süresi }\end{array}$ & Analiz Yöntemi & Çalışma Sonuçları \\
\hline 1 & $\begin{array}{c}\text { Kim ve } \\
\text { ark., }^{64} 2014\end{array}$ & 15 hasta & $\begin{array}{l}\text { Yönlendirilmiş kemik } \\
\text { rejenerasyonu }\end{array}$ & Toz & - & 2. ve 4. ay & - & Histolojik Analiz & $\begin{array}{l}\text { 2. ayda sınırlı oranda yeni kemik doku oluşumu; } \\
\text { 4. ayda, yeni oluşan kemik doku oranında artış }\end{array}$ \\
\hline 2 & $\begin{array}{c}\text { Joshi ve } \\
\text { ark., } 2016\end{array}$ & 15 hasta & Soket koruma & Toz & $\begin{array}{c}\text { Sentetik } \\
\text { kemik grefti } \\
\text { ve boş çekim } \\
\text { soketi }\end{array}$ & 4. ay & 4 ay & $\begin{array}{l}\text { Radyolojik ve } \\
\text { Histolojik Analiz }\end{array}$ & $\begin{array}{c}\text { Radyolojik sonuçlar; alveoler kretin hacimsel } \\
\text { değişiklikleri sentetik kemik greftine uygulanan } \\
\text { gruba göre daha düsüük } \\
\text { Histolojuk sonuçlar; yeni kemik oluşumu greft } \\
\text { sahalarında benzer }\end{array}$ \\
\hline 3 & $\begin{array}{l}\text { Lee ve ark., } \\
2012\end{array}$ & $\begin{array}{l}37 \text { hasta; } \\
54 \text { implant }\end{array}$ & $\begin{array}{l}\text { İmplant çevresi kemik } \\
\text { defekti }\end{array}$ & Toz & - & - & 31 ay & $\begin{array}{l}\text { Klinik ve } \\
\text { Radyolojik } \\
\text { Analiz }\end{array}$ & $\begin{array}{c}\text { Klinik sonuçlar; } 2 \text { hastada implant kaybı } \\
\text { Radyolojik sonuçlar; Marjinal kemik kaybı } 0.33 \pm \\
0.63 \mathrm{~mm}\end{array}$ \\
\hline 4 & $\begin{array}{l}\text { Jeong ve } \\
\text { ark., }{ }^{6} 2011\end{array}$ & 51 hasta & $\begin{array}{l}\text { Maksiller sinüs } \\
\text { ogmentasyonu }\end{array}$ & Toz & - & $\begin{array}{l}\text { 3. ve } 6 . \\
\text { Ay; } 8 \\
\text { hasta }\end{array}$ & - & $\begin{array}{c}\text { Klinik ve } \\
\text { Histolojik analiz }\end{array}$ & 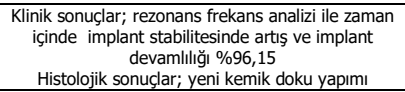 \\
\hline 5 & $\begin{array}{l}\text { Jun ve ark., } \\
2014\end{array}$ & 43 hasta & $\begin{array}{l}\text { Maksiller sinüs } \\
\text { ogmentasyonu }\end{array}$ & Toz & Ksenogreft & 4. ay & 4 ay & $\begin{array}{l}\text { Klinik, Radyolojik } \\
\text { ve Histolojik Analiz }\end{array}$ & $\begin{array}{l}\text { Her iki grupta da benzer oranda implant stabilitesi, } \\
\text { ortalama kemik yüksekliği ve yeni kemik yüzdesi }\end{array}$ \\
\hline 6 & $\begin{array}{l}\text { Kim ve } \\
\text { ark., } 2013\end{array}$ & 12 hasta & $\begin{array}{c}\text { Yönlendirilmiş kemik } \\
\text { rejenerasyonu, Soket } \\
\text { koruma, Maksiller } \\
\text { sinüs ve alveoler } \\
\text { kemik ogmentasyonu }\end{array}$ & Blok & - & 10. hafta & - & $\begin{array}{l}\text { Klinik ve } \\
\text { Histolojik Analiz }\end{array}$ & $\begin{array}{l}\text { Klinik sonuçlar; } 1 \text { hastada greft yüzeyinde açılma; } \\
\text { osteointegrasyon başarısılzlğına bağlı } 1 \text { implant } \\
\text { kaybı } \\
\text { Histolojik sonuçlar; dentin matrisi içine gömülmüş } \\
\text { osteositler ve rezorbe olan ODKG çevresinde yeni } \\
\text { kemik doku oluşumu }\end{array}$ \\
\hline 7 & $\begin{array}{l}\text { Lee ve ark., } \\
2013\end{array}$ & $\begin{array}{l}9 \text { hasta; } \\
29 \text { diş } \\
\text { çekimi }\end{array}$ & $\begin{array}{l}\text { Alveoler kret } \\
\text { ogmentasyonu }\end{array}$ & Blok veya Toz & - & - & $3 \mathrm{yll}$ & Klinik Analiz & $\begin{array}{c}1 \text { hastada greft yüzeyinde açılma; } 1 \text { hastada } \\
\text { hematom gelisimi; } \\
\text { Implant devamllığı } \% 96\end{array}$ \\
\hline 8 & $\begin{array}{c}\text { Pohl ve } \\
\text { ark.," } 2017\end{array}$ & $\begin{array}{l}20 \text { hasta; } \\
28 \text { implant }\end{array}$ & $\begin{array}{c}\text { Alveoler kret } \\
\text { ogmentasyonu }\end{array}$ & Toz & - & - & $\begin{array}{l}6,12 \\
\text { ve } 24 \\
\text { ay }\end{array}$ & Klinik Analiz & $\begin{array}{c}\text { Kemik kayb;; } \\
\text { 12. ay } 0,4 \mathrm{~mm} ; \\
\text { 24. ay } 0,6 \mathrm{~mm} \\
\text { Cep derinliği; } \\
\text { 12. ay } 1 \mathrm{~mm} \\
\text { 24. ay } 2 \mathrm{~mm} \\
\end{array}$ \\
\hline 9 & $\begin{array}{l}\text { Parvini ve } \\
\text { ark. }^{.8} 2018\end{array}$ & 30 hasta & $\begin{array}{l}\text { Alveoler kret } \\
\text { ogmentasyonu }\end{array}$ & Blok & $\begin{array}{l}\text { Otojen blok } \\
\text { kemik grefti }\end{array}$ & - & $\begin{array}{c}26 \\
\text { hafta }\end{array}$ & $\begin{array}{l}\text { Radyolojik } \\
\text { Analiz }\end{array}$ & $\begin{array}{c}\text { Kontrol grubuna göre düs̆̈̈k oranda greft yüzey } \\
\text { alanı varlı̆ıı ve daha yüksek oranda yeni kemik } \\
\text { oluşumu }\end{array}$ \\
\hline 10 & 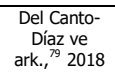 & 9 hasta & Soket Koruma & Toz & $\begin{array}{l}\text { Boş çekim } \\
\text { soketi }\end{array}$ & - & $\begin{array}{l}\text { 8. ve } \\
16 . \\
\text { hafta }\end{array}$ & $\begin{array}{l}\text { Radyolojik } \\
\text { Analiz }\end{array}$ & $\begin{array}{c}\begin{array}{c}\text { Kontrol grubuna göre daha düş̧ük alveoler kemik } \\
\text { kaybı }\end{array} \\
\text {. }\end{array}$ \\
\hline 11 & $\begin{array}{c}\text { Kim ve } \\
\text { ark. }{ }^{80} 2014\end{array}$ & $\begin{array}{l}13 \text { hasta; } \\
15 \text { implant }\end{array}$ & Soket Koruma & $\begin{array}{l}\text { Blok ve/veya } \\
\text { Toz }\end{array}$ & - & $\begin{array}{l}\text { 3. ay }(1 \\
\text { hasta) } \\
4 . \text { ay } \\
\text { (2 hasta) }\end{array}$ & $\begin{array}{c}1,2 \mathrm{ve} \\
3 \mathrm{yil}\end{array}$ & $\begin{array}{c}\text { Klinik, } \\
\text { Radyolojik ve } \\
\text { Histolojik Analiz }\end{array}$ & $\begin{array}{c}\text { Klinik sonuçlar; } 2 \text { hastada greft yüzeyinde açlma } \\
\text { Radyolojik; } 3 \text { hastada marjinal kemik kaybı } \\
\text { Histolojik sonuçlar; anjiyogenez açısından zengin, } \\
\text { gevşek fibröz dokuya sahip yeni oluşmuş kemik } \\
\text { dokusu }\end{array}$ \\
\hline 12 & $\begin{array}{c}\text { Kim ve } \\
\text { ark., }\end{array}$ & 22 hasta & $\begin{array}{l}\text { Maksiller sinüs } \\
\text { ogmentasyonu }\end{array}$ & Toz & $\begin{array}{c}\text { Sentetik } \\
\text { kemik grefti }\end{array}$ & - & $1 \mathrm{yll}$ & $\begin{array}{l}\text { Radyolojik } \\
\text { Analiz }\end{array}$ & Her iki grupta da benzer oranda kemik rezorpsiyonu \\
\hline 13 & $\begin{array}{c}\text { Pang ve } \\
\text { ark., }{ }^{82} 2017\end{array}$ & $\begin{array}{l}24 \text { hasta; } \\
33 \text { defektif } \\
\text { saha }\end{array}$ & $\begin{array}{l}\text { Alveoler kret } \\
\text { ogmentasyonu }\end{array}$ & Toz & Ksenogreft & 6. ay & 6 ay & $\begin{array}{c}\text { Klinik, } \\
\text { Radyolojik ve } \\
\text { Histolojik Analiz } \\
\end{array}$ & $\begin{array}{l}\text { Her iki grupta da benzer oranda kemik kazanımı, } \\
\text { implantın primer stabilitesi ve yeni kemik yüzdesi }\end{array}$ \\
\hline
\end{tabular}


Hayvan modellerinde deneysel olarak oluşturulan implant çevresi kemik defektlerinin tamirinde ODKG'nin, kemik yapımı üzerine etkisini incelemiştir. Altı adet erkek, küçük domuzun kullanıldığı çalışmada, alt çeneden 4 adet molar diş çekimi yapılmışıı. İşlemden 10 gün sonra, çekim soketlerine boyun yüzeyi 2 mm açıkta kalacak şekilde, 4 adet implant uygulanmıştır. Çekilmiş molar dişlerden elde edilen ODKG'leri, üç adet implantın defekt bölgesini halka yapısında saracak şekilde yerleştirilmiş ve 1 adet implantın defekt bölgesi greftlenmeden kontrol grubu oluşturulmuştur. Radyolojik ve histolojik veriler 4,8 ve 12. haftalarda incelenmiştir. Araştırmacılar, otojen diş kemik greftleri ile defekt çevresinde yeni kemik oluşumunun sağlandığını ve kemik-implant yüzey bağlantısının kontrol grubuna göre yüksek olduğunu bildirmişlerdir. ${ }^{73}$

Lee ve arkadaşları, ${ }^{74}$ sinüs ogmentasyonunda kemik doku oluşumunda ODKG'nin etkisini incelemişlerdir. 18-24 aylık 5 adet küçük domuzun kullanıldığı çalışmada, sağ maksiller sinüs ODKG ve sol maksiller sinüs sentetik kemik grefti ile ogmente edilmiştir. Histolojik örnekler 12. haftada alınmıştır ve araştırmacılar, her iki grupta da yeni kemik yapımının gözlendiğini rapor etmiştir. Çalışmanın sonuçlarına göre ODKG'nin ogmentasyon cerrahilerinde alternatif bir greft olarak kullanılabileceği bildirilmiştir.

\section{Klinik Çalışmalar}

ODKG'nin ogmentasyon üzerine etkinliği ve klinik başarısı değerlendirildiğinde, araşıtımacılar, şimdiki greftlere alternatif oluşturabileceğini öne sürmüşlerdir. Bir çalışmada, 12 olguda kullanılan blok halindeki ODKG'nin klinik sonuçları ve histolojik verilerini değerlendirilmiştir. Bu amaçla, yönlendirilmiş kemik rejenerasyonu, soket koruma, maksiller sinüs ve alveoler kemik ogmentasyonu uygulanmıştır ve histolojik örnekler 2,5 ay sonra alınmıştır. Klinik sonuçlarda, 1 hastada greft yüzeyinde açılma rapor edilmiş ve osteointegrasyon başarısızlığına bağı 1 implant kaybı yaşanmıştır. Histolojik değerlendirmede, demineralize dentin matriksi içine gömülmüş osteositler ve rezorbe olan ODKG çevresinde yeni kemik doku oluşumunun sağlandığı bildirilmiştir. ${ }^{75}$

Lee ve arkadaşları ${ }^{76}$ yaptıkları çalışmada, üç boyutlu alveoler kret ogmentasyonunda ODKG kullanmışlardır. Dokuz vakanın yer aldığı çalışmada, toplamda 29 adet diş çekimi gerçekleştirilmiş ve çekilen dişler blok veya toz halinde greftlemede kullanılmışır. Operasyon sonrası 1 hastada greft yüzeyinde açılma ve 1 hastada hematom geliştiği rapor edilmiştir.
Ortalama üç yıl takibi yapılan hastalarda, implant devamlıı̆ı̆ı $\% 96$ olarak bildirilmiştir.

Bir diğer çalışmada, Pohl ve arkadaşları, ${ }^{77} 20$ hastada ODKG olarak distopik dişler kullanarak alveoler kret ogmentasyonu yapmışlardır. Hastalara toplamda 28 implant uygulanmış ve operasyon sonrası 6,12 ve 24 . aylarda yapılan klinik muayenelerde, implant çevresi kemik kaybı, cep derinliği ve kanamayı incelemiştir. Kemik kaybı 6. ayda gözlenmemiş ancak 12 ve 24 . aylarda sırasıyla, $0,4 \mathrm{~mm}$ ve $0,6 \mathrm{~mm}$ olarak ölçülmüştür. Cep derinliği 12 . ayda $1 \mathrm{~mm}$ ve 24 . ayda $2 \mathrm{~mm}$ olarak bildirilmiş ve sondalamada kanama gözlenmediği rapor edilmiştir. Bu nedenle, ODKG'nin, alveoler kemiğin ogmentasyonu ve kemik içi defektlerin tedavisinde uygun bir greft olduğu bildirilmiştir.

Lateral alveoler kret ogmentasyonunda, ODKG'nin etkisinin araştırılı̆̆ı bir çalışmada, 30 hastanın $15^{\prime}$ ine tam retantif dişlerden elde edilen blok ODKG ve $15^{\prime}$ ine ramus donör sahadan elde edilen otojen blok greft uygulanmıştır. Yirmi altıncı haftada alınan konik ışınlı bilgisayarı tomografi üzerinde greft alanı ve greft-alıcı saha bağlantısı incelenmiştir. Çalışma sonuçlarında, ODKG'de, greft yüzey alanının daha düşük olduğu ve yeni kemik oluşumu açısından olumlu sonuçlar sunduğu bildirilmiştir. ${ }^{78}$

ODKG'nin yeni kemik yapımı üzerine etkisinin incelendiği bir çalışmada, 15 hastada yönlendirilmiş kemik rejenerasyonunda otojen diş kemik greftleri kullanıımışır. Histolojik analiz için 2. ve 4. ayda doku örnekleri alınmışıı. Araştırmacılar, 2. ayda yeni kemik doku oluşumunun sınırlı olduğunu ancak, 4. ayda, greftin yeni oluşan kemik doku ile kaynaştığını ve yeni oluşan kemik dokunun rezorbe olan greftin yerini aldığını bildirmişlerdir. Çalışma sonucunda, ODKG'lerin osteokondüksiyon ile kemik iyileşmesini olumlu yönde etkilediği bildirilmiştir. ${ }^{64}$

Çekim soketlerinde ODKG'nin kullanıldığı çalışmalarda, iyi bir iskelet materyali olarak görev aldığı bildirilmiştir. Del Canto-Diaz ve arkadaşları ${ }^{79}$ yaptıkları çalışmada, 9 hastanın alveoler çekim soketindeki hacimsel değişikliği kontrol grubu oluşturarak incelemiştir. Araştırmacılar, hastalardan iki adet diş çekimi gerçekleştirmiştir. Çalışmada, bir soket greftlenirken diğer soket kontrol grubu olarak korunmuştur. Alveoler soketin hacimsel değişikliği operasyonu sonrası, 8 . ve 16. haftalarda değerlendirilmiştir. Radyolojik ölçümler, koronal, apikal ve medial alveoler bölgelerden yapılmışıı. Bu çalışmanın sonucunda, ODKG'nde alveoler kemik kaybının kontrol grubuna göre daha düşük olduğu bildirilmiştir. Bu nedenle, iyi bir yer tutucu materyal olarak kullanılabileceği öngörülmüştür. 
Kim ve arkadaşları ${ }^{80}$ yaptıkları çalışmada, soket korumada ODKG'nin klinik başarısını değerlendirmişlerdir. Araştırmacılar, 13 hastada 15 adet diş çekmiş ve kemik defektinin boyutuna göre sırasıyla; 10 çekim soketinde toz, 4 çekim soketinde toz ve blok, 1 çekim soketinde blok ODKG kullanmışlardır. İmplant cerrahisi, ogmentasyonu takiben ortalama 1,2 ayda (2 hafta ile 5 ay arasında) uygulanmıştır ve marjinal kemik seviyesindeki değişiklik 1., 2. ve 3. yillarda alınan radyografiler ile incelenmiştir. Araştırmacılar, 2 hastada greft yüzeyinin açıldığını ve radyolojik değerlendirmede, 3 hastada marjinal kemik kaybı yaşandığını rapor etmişlerdir. Histolojik örneklerde, anjiyogenez açısından zengin, gevşek fibröz dokuya sahip yeni oluşmuş kemik izlendiğini bildirmişlerdir. Bu nedenle, ODKG'nin kemik yapımında etkili olduğunu ve osteokondüktif özelliği ile soket korumasında bir alternatif olabileceğini belirtmişlerdir.

ODKG'nin osteokondüktif özelliğinin değerlendirilmesi için sentetik ve ksenogreft kemik greftleri ile karşılaştırıldığı kontrollü çalışmalar literatürde yer almaktadır. Joshi ve arkadaşları ${ }^{65}$ yaptıkları çalışmada, toplamda 15 hastayı tedavi etmişlerdir ve her bir hastadan 3 adet diş çekimi yapılmışır. Diş çekim soketlerinin birine sentetik ve birine ODKG yerleştirilmiştir. Bir çekim soketi ise kontrol grubu olarak boş bırakılmıştır. Radyolojik değerlendirme, 4. ayda alınan tomografi üzerinden yapılmış ve histolojik değerlendirme için, implant cerrahisi öncesi kemik örnekleri alınmıştır. Sonuçlarda, alveoler kretin hacimsel değişikliklerinin, ODKG uygulanan grupta daha az olduğu ve yeni kemik oluşumunun greft sahalarında benzer olduğu bildirilmiştir. Araştırmacılar, ODKG'nin, sentetik kemik grefti ile karşılaştırıldığında üstün sonuçlar verdiğini rapor etmişlerdir ve buna dayanarak, ODKG'nin geleneksel kemik greft materyallerine göre daha iyi bir alternatif olarak hizmet edebileceği sonucuna varmışlardır.

Lee ve arkadaşları ${ }^{66}$ yaptıkları retrospektif bir çalışmada, ODKG'nin klinik başarısını incelemiştir. Otuz yedi hastanın yer aldığı çalışmada, toplamda 54 implant çevresine ODKG uygulanmıştır. Araştırmacılar, iki hastada (4 implant) implant kaybı yaşandığını ve ortalama 31 aylık takip sürecinde, marjinal kemik kaybının $0,33 \pm 0,63 \mathrm{~mm}$ olduğunu rapor etmişlerdir. Bu çalışma sonuçlarına göre, ODKG'nin kemik iyileşmesini sağladığı ve güvenli bir greft olduğu belirtilmiştir. Başka bir retrospektif çalışmada ise, maksiller sinüs ogmentasyonunda ODKG'nin etkinliği incelenmiştir. Yirmi iki hastanın yer aldığı çalışmada 11 hastaya, ODKG ve 11 hastaya sentetik kemik grefti uygulanmıştır. Operasyonu takiben 1 . yılda kemik rezorpsiyonu karşılaştırımış ve rezorpsiyon oranının her iki grup için de benzer olduğu rapor edilmiştir. Araştırmacılar, maksiller sinüs ogmentasyonu için alternatif bir greft olarak ODKG'nin kullanılabileceğini bildirmişlerdir. ${ }^{81}$

Jeong ve arkadaşları ${ }^{67}$ yaptıkları çalışmada, 2009-2010 yılları arasında ODKG kullanılarak 51 hastaya maksiller sinüs ogmentasyonu uygulamışlardır. Araştırmacılar, klinik olarak rezonans frekans analizi ile implant stabilitesini ve implant sağ kalımını incelemişlerdir. İmplant stabilitesi, erken ve geç yüklemede ölçülüp karşılaştırımıştır. Elli bir hastanın 8'inden implant cerrahisi sonrası veya maksiller sinüs ogmentasyonunu takiben 3 ile 6 . aylarda kemik örnekleri alınmıştır. Klinik sonuçlarda, araştırmacılar, implant stabilitesinin zaman içinde arttığını rapor etmişlerdir ve implant devamlılığının \% 96,15 olduğunu bildirmişlerdir. Histolojik incelemede, ODKG'nin osteoklast ve osteoblast hücreleri ile çevrelendiği ve kemik greftinin aşamalı olarak rezorpsiyona uğrayarak yeni kemik yapımının gerçekleştiği rapor edilmiştir. Bu çalışmanın sonuçlarına göre, araştırmacılar, ODKG'nin maksiller sinüs ogmentasyonu için uygun bir materyal olduğunu belirtmişlerdir.

ODKG'nin kemik ogmentasyonu üzerine etkisinin ksenogreft kemik greft ile karşılaştırıldığı bir çalışmada, diş çekimini takiben 2 ile 4 hafta arasında, 24 hastanın $15^{\prime} \mathrm{i}$ ODKG ve 9'u ksenogreft ile tedavi edilmiştir. Toplamda, 33 defektif sahanın ogmente edildiği çalışmada, kemik kazanımı, implantın primer stabilitesi ve histolojik veriler karşılaştııımışıı. Çalışma sonuçlarında, araştırmacılar, ODKG'nin ksenogreft ile benzer bulgular gösterdiğini ve yeni kemik oluşumunun sağlandığını bildirmişlerdir. ${ }^{82}$

Jun ve arkadaşları ${ }^{68}$ yaptıkları çalışmada, ODKG'nin maksiller sinüs ogmentasyonundaki etkinliğini ksenogreft kemik grefti ile karşılaştırmışlardır. Alveoler kemik yüksekliği 5 mm'den az olan 43 hasta çalışmaya alınmışıı. Randomize olarak gruplandırılan hastalarda bir gruba ksenogreft kemik grefti ve bir gruba ODKG uygulanmışıı. Dört aylık iyileşme sonrası gruplar, klinik, radyolojik ve histolojik olarak incelenmiştir. Sonuçlarda, implant stabilitesi, ortalama kemik yüksekliği ve yeni kemik yüzdesi açısından gruplar arasında anlamlı bir farklılık bulunmamıştır. Bu çalışmanın sonuçlarına göre, ODKG'nin alternatif bir greft olarak kullanılabileceği rapor edilmiştir.

\section{SONUÇ}

ODKG, fiziksel ve biyolojik yapısı kemik doku ile benzer olan ve biyolojik olarak rezorbe olabilen bir materyaldir. 
ODKG'nin, kemik doku üzerinde yenileme ve iyileştirme özelliği organik yapısında yer alan KMP, kollajen ve kollajen olmayan proteinler ile sağlanır. Bu proteinler, dentin dokusunun mineralizasyonunda rol oynar ve mineral birikim fazı için bir iskelet oluşturur. Dentin dokusunun mineral içeriğinin büyük bir yüzdesi HA kristallerinden oluşmaktadır. Bu mineral içeriği hem dokuya dayanıklılık kazandırır hem de yeni kemik doku oluşumunda osteokondüksiyon sağlar. Bu nedenle, ODKG, kemik grefti seçiminde önemli bir alternatif olarak kullanılabilir.

ODKG ile ilgili yapılan olgu çalışmaları kemik yapımını sağlaması açısından umut vaat edici olsa da klinik kullanımını arttırmak için kontrollü ve uzun dönem çalışmalara gereksinim vardır . Bireyin kendi diş dokusundan elde edildiği için maliyeti düşük ve eldesi kolay bir yöntem olması açısından ODKG cerrahi uygulamalarda avantajlı bir yöntemdir.

NOT: Bu makale yazarlarından hiçbirinin makalede bahsi geçen konu veya malzemeyle ilgili herhangi bir ilişkisi, bağlantısı veya parasal çıkar durumu söz konusu değildir.

\section{KAYNAKLAR}

1. Bhatt RA, Rozental TD. Bone graft substitutes. Hand Clinic. 2012; 28: 457-68.

2. Köse Hİ, Özden B. Ağız ve çene cerrahisinde periosteumun greft olarak kullanımı: literatür derlemesi. Atatürk Uni Diş Hek Fak Derg 2016; 16 : 137- 40.

3. Chiarello E, Cadossi M, Tedesco G, Capra P. Autograft, allograft and bone substitutes in reconstructive orthopedic surgery. Aging Clin Exp Res 2013; 25: 101-3.

4. Khan SN, Cammisa JFP, Sandhu HS, Diwan AD, Girardi FP, Lane JM. The biology of bone grafting. J Am Acad Orthop Surg 2005; 13: 77-86.

5. Sukumar S, Drizhal I. Bone grafts in periodontal therapy. Acta Medica 2008; 51: 203-7.

6. Şençimen M, Gülses A, Varol A, Okçu KM, Bayar GR. Mandibuler simfiz bölgesinden kemik grefti alınmasına yönelik iki basit cerrahi teknik. J Dent Fac Atatürk Uni 2010; 3: 12-6.

7. Esposito M, Grusovin MG, Felice $P$, Karatzopoulos G, Worthington HV, Coulthard P. The efficacy of horizontal and vertical ridge augmentation procedures for dental implants. a cochrane systematic review. Eur J Oral Implantol 2009; 2; 167-84.
8. Chiapasco M, Casentini $P$, Zaniboni $M$. Bone augmentation procedures in implant dentistry. Int J Oral Maxillofac Implants 2009; 24: 237-59.

9. Kim YK, Kim SG, Byeon JH, Lee HJ, Um IU, Lim SC, Kim SY. Development of a novel bone grafting material using autogenous teeth. Oral Surg Oral Med Oral Pathol Oral Radiol Endod 2010; 109: 496-503.

10. Buser D. 20 years of guided bone regeneration in implant dentistry. 2th. New Malden: Surrey: Quintessence Publishing; 2010. p.1-15.

11. White DJ. The application of in vitro models to research on demineralization and remineralization of the teeth. Adv Dent Res 1995; 9: 175-93.

12. Jones SJ, Boyde A. Ultrastructure of dentin and dentinogenesis. In: Linde A. editor. Dentin and dentinogenesis. 2th. Boca Raton: Florida: CRC Press; 1984. p. 81-134.

13. Goldberg $M$, Kulkarni $A B$, Young $M$, Boskey $A$. Dentin: structure, composition and mineralization. Front Biosci (Elite ed.); 2011; 3: 711-35.

14. He L, Hao Y, Zhena L, Liu H, Shao M, Xua X, Liang K, Gao Y, Yuan H, Li J, Li J, Cheng L, van Loveren C. Biomineralization of dentin. J Struct Biol 2019; 207: 115-22.

15. Okamoto M, Takahashi Y, Komichi S, Ali M, Yoneda $\mathrm{N}$, Ishimoto $\mathrm{T}$, Nakano $\mathrm{T}$, Hayashi M.Novel evaluation method of dentin repair by direct pulp capping using high-resolution micro-computed tomography. Clin Oral Investig 2018; 22: 2879-87.

16. Cao CY, Mei ML, Li QL, Lo EC, Chu CH. Methods for biomimetic remineralization of human dentine: a systematic review. Int J Mol Sci 2015; 16: 461527.

17. Silver FH, Langley KH, Trelstad RL. Type I collagen fibrillogenesis: initiation via reversible linear and lateral growth steps. Biopolymers 2004; 18: 252335.

18. Waddington RJ, Hall RC, Embery G, Lloyd DM. Changing profiles of proteoglycans in the transition of predentine to dentine. Matrix Biol 2003; 22:15361.

19. Schilke R, Lisson JA, Bauss O, Geurtsen W. Comparison of the number and diameter of dentinal tubules in human and bovine dentine by scanning electron microscopic investigation. Arch Oral Biol 2000; 45:355-61.

20. de Mattos Pimenta Vidal C, Leme-Kraus AA, Rahman M, Farina AP, Bedran-Russo AK. Role of proteoglycans on the biochemical and 
biomechanical properties of dentin organic matrix. Arch Oral Biol 2017; 82: 203-8.

21. Boskey AL. Biomineralization: conflicts, challenges, and opportunities. J Cell Biochem Suppl 1998; 8391.

22. Nudelman F, Lausch AJ, Sommerdijk NA, Sone ED. In vitro models of collagen biomineralization. J Struct Biol 2013; 183: 258-69.

23. Barralet J, Best S, Bonfield W. Carbonate substitution in precipitated hydroxyapatite: an investigation into the effects of reaction temperature and bicarbonate ion concentration. J Biomed Mater Res 1998; 41: 79-86.

24. Teruel JD, Alcolea A, Hernández A, Ortiz AJ. Comparison of chemical composition of enamel and dentine in human, bovine, porcine and ovine teeth. Arch Oral Biol 2015; 60: 768-75.

25. Youssef AR, Emara $R$, Taher MM, Al-Allaf FA, Almalki M, Almasri MA, Siddiqui SS. Effects of mineral trioxide aggregate, calcium hydroxide, biodentine and Emdogain on osteogenesis, Odontogenesis, angiogenesis and cell viability of dental pulp stem cells. BMC Oral Health 2019; 2: 19:133.

26. Ritchie $H$. The functional significance of dentin sialoprotein-phosphophoryn and dentin sialoprotein. Int J Oral Sci 2018; 10: 31.

27. Mazzoni A, Tjäderhane L, Checchi V, Di Lenarda R, Salo T, Tay FR, Pashley DH, Breschi L. Role of dentin MMPs in caries progression and bond stability. J Dent Res 2015; 94: 241-51.

28. Guven EP, Yalvac ME, Sahin F, Yazici MM, Rizvanov AA, Bayirli G. Effect of dental materials calcium hydroxide-containing cement, mineral trioxide aggregate, and enamel matrix derivative on proliferation and differentiation of human tooth germ stem cells. J Endod 2011; 37: 650-6.

29. Alford AI, Hankenson KD. Matricellular proteins: extracellular modulators of bone development, remodeling, and regeneration. Bone 2006; 38: 749-57.

30. Jadlowiec JA, Zhang X, Li J, Campbell PG, Sfeir C. Extracellular matrix-mediated signaling by dentin phosphophoryn involves activation of the Smad pathway independent of bone morphogenetic protein. J Biol Chem 2006; 281: 5341-7.

31. Van der Rest M, Garrone R. Collagen family of proteins. FASEB J 1991; 5: 2814-2823.

32. Iohara $K$, Nakashima $M$, Ito $M$, Ishikawa $M$, Nakasima A, Akamine A. Dentin regeneration by dental pulp stem cell therapy with recombinant human bone morphogenetic protein 2. J Dent Res 2004; 83: 590-5.

33. Ike M, Urist MR. Recycled dentin root matrix for a carrier of recombinant human bone morphogenetic protein. J Oral Implantol 1998; 24: 124-32.

34. Steiglitz BM, Ayala M, Narayanan K, George A, Greenspan DS. Bone morphogenetic protein-1/ Tolloid-like proteinases process dentin matrix protein-1. J Biol Chem 2004; 279: 980-6.

35. Chen S, Gluhak-Heinrich J, Martinez M, Li T, Wu Y, Chuang H-H, Chen L, Dong J, Gay I, MacDougall $M$. Bone morphogenetic protein-2 mediates dentin sialophosphoprotein expression and odontoblast differentiation via NF-Y signaling. J Biol Chem 2008; $283: 19359-70$.

36. Ni SL, Zhang J, Liu X, Li XW, Sun YJ, Zhang $X$, Wang L, Lu JJ, Cui Y, Zheng CY, Han B, Sun HC. Effects of human bone morphogenetic protein 2 (hBMP2) on tertiary dentin formation. Am J Transl Res 2018; 10: 2868-76.

37. Um IW, Ku JK, Lee BK, Yun PY, Lee JK, Nam JH. Postulated release profile of recombinant human bone morphogenetic protein-2 (rhBMP-2) from demineralized dentin matrix. J Korean Assoc Oral Maxillofac Surg 2019; 45: 123-8.

38. Prockop DJ, Sieron AL, Li SW. Procollagen Nproteinase and procollagen C-proteinase. Two unusual metalloproteinases that are essential for procollagen processing probably have important roles in development and cell signaling. Matrix Biol 1998; 16: 399-408.

39. von Marschall Z, Fisher LW. Dentin sialophosphoprotein (DSPP) is cleaved into its two natural dentin matrix products by three isoforms of bone morphogenetic protein-1 (BMP1). Matrix Biol 2010; 29: 295-303.

40. Li W, Chen L, Chen Z, Wu L, Feng J, Wang F, Shoff L, Li X, Donly KJ, MacDougall M, Chen S. Dentin sialoprotein facilitates dental mesenchymal cell differentiation and dentin formation. Sci Rep 2017; 7: 300 .

41. Almushayt A, Narayanan K, Zaki AE, George A. Dentin matrix protein 1 induces cytodifferentiation of dental pulp stem cells into odontoblasts. Gene Ther 2006; 13: 611-20.

42. Alimohamad $H$, Habijanac $T$, Larjava $H$, Häkkinen L. Colocalization of the collagen-binding proteoglycans decorin, biglycan, fibromodulin and lumican with different cells in human gingiva. J Periodontal Res 2005; 40: 73-86. 
43. Bertassoni LE, Orgel JP, Antipova O, Swain MV. The dentin organic matrix - limitations of restorative dentistry hidden on the nanometer scale. Acta Biomat 2012; 8: 2419-33.

44. Christiansen DL, Huang EK, Silver FH. Assembly of type I collagen: fusion of fibril subunits and the influence of fibril diameter on mechanical properties. Matrix Biol 2000; 19 :409-20.

45. Milan AM, Sugars RV, Embery G, Waddington RJ. Modulation of collagen fibrillogenesis by dentinal proteoglycans. Calcif Tissue Int 2005; 76:127-35.

46. Di Foggia M, Prati C, Gandolfi MG, Taddei P. An in vitro study on dentin demineralization and remineralization: Collagen rearrangements and influence on the enucleated phase. J Inorg Biochem 2019; 193: 84-93.

47. Murata M. Collagen biology for bone regenerative surgery. J Korean Assoc Oral Maxillofac Surg 2012; 38: 321-325.

48. Iohara $K$, Nakashima $M$, Ito $M$, Ishikawa $M$, Nakasima A, Akamine A. Dentin regeneration by dental pulp stem cell therapy with recombinant human bone morphogenetic protein 2.J Dent Res 2004; 83: 590-5.

49. Sereda G, VanLaecken A, Turner JA.Monitoring demineralization and remineralization of human dentin by characterization of its structure with resonance-enhanced AFM-IR chemical mapping, nanoindentation, and SEM. Dent Mater 2019; 35: 617-26.

50. Wiesmann $H$, Meyer $U$, Plate $U$, Höhling $H$. Aspects of collagen mineralization in hard tissue formation. Int Rev Cytol 2004; 242: 121-56.

51. Huang B, Sun Y, Maciejewska I, Qin D, Peng T, McIntyre B, Wygant J, Butler WT, Qin C. Distribution of SIBLING proteins in the organic and inorganic phases of rat dentin and bone. Eur J Oral Sci 2008; 116: 104-12.

52. Bertassoni LE. Dentin on the nanoscale: Hierarchical organization, mechanical behavior and bioinspired engineering. Dent Mater 2017; 33: 637-49.

53. Niu LN, Jee SE, Jiao K, Tonggu L, Li M, Wang $L$, Yang YD, Bian JH, Breschi L, Jang SS, Chen $\mathrm{JH}$, Pashley $\mathrm{DH}$, Tay FR. Collagen intrafibrillar mineralization as a result of the balance between osmotic equilibrium and electroneutrality. Nat Mater 2017; 16: 370-8.

54. Gulseren G, Tansik G, Garifullin R, Tekinay AB, Guler OB. Dentin phosphoprotein mimetic peptide nanofibers promote biomineralization. Macromol Biosci 2019; 19: e1800080.

55. Suzuki S, Sreenath T, Haruyama N, Honeycutt C, Terse A, Cho A, Kohler T, Müller R, Goldberg M, Kulkarni AB. Dentin sialoprotein and dentin phosphoprotein have distinct roles in dentin mineralization. Matrix Biol 2009; 28: 221-9.

56. Srinivasan R, Chen B, Gorskil JP, George A. Recombinant expression and characterization of dentin matrix protein 1 . Connect Tissue Res 1999; 40: 251-8.

57. Padovano J, Ravindran $S$, Snee $P$, Ramachandran A, Bedran-Russo A, George A. DMP1-derived peptides promote remineralization of human dentin. J Dent Res 2015; 94: 608-14.

58. Orsini G, Ruggeri A, Mazzoni A, Nato F, Falconi M, Putignano A, Di Lenarda R, Nanci A, Breschi L. Immunohistochemical localization of dentin matrix protein 1 in human dentin. Eur J Histochem 2008; 52: 215-20.

59. He LH, Swain MV. Understanding the mechanical behaviour of human enamel from its structural and compositional characteristics. J Mech Behav Biomed Mater 2008; 1: 18-29.

60. Goldberg M, Takagi M. Dentine proteoglycans: composition, ultrastructure and functions. Histochem J 1993; 25: 781-806.

61. Gandhi NS, Mancera RL. The structure of glycosaminoglycans and their interactions with proteins. Chem Biol Drug Des 2008; 72: 455-82.

62. Stankoska K, Sarram L, Smith S, Bedran-Russo AK, Little CB, Swain MV, Bertassoni LE. Immunolocalization and distribution of proteoglycans in carious dentine. Aust Dent J 2016; 61: 288-97.

63. Bertassoni LE, Swain MV. The contribution of proteoglycans to the mechanical behavior of mineralized tissues. J Mech Behav Biomed Mater 2014; 38: 91-104.

64. Kim YK, Kim SG, Bae JH, Um IW, Oh JS, Jeong KI. Guided bone regeneration using autogenous tooth bone graft in implant therapy: case series. Implant Dent 2014; 23: 138-43.

65. Joshi CP, Dani NH, Khedkar SU. Alveolar ridge preservation using autogenous tooth graft versus beta-tricalcium phosphate alloplast: A randomized, controlled, prospective, clinical pilot study. J Indian Soc Periodontol 2016; 20: 429-34.

66. Lee JY, Kim YK. Retrospective cohort study of autogenous tooth bone graft. Oral Biol Res 2012; 36: 39-43. 
67. Jeong KI, Kim SG, Kim YK, Oh JS, Jeong MA, Park JJ. Clinical study of graft materials using autogenous teeth in maxillary sinus augmentation. Implant Dent 2011; 20: 471-5.

68. Jun SH, Ahn JS, Lee JI, Ahn KJ, Yun PY, Kim YK. A prospective study on the effectiveness of newly developed autogenous tooth bone graft material for sinus bone graft procedure. J Adv Prosthodont 2014; 6: 528-38.

69. Upadhyay $P$, Blaggana $V$, Tripathi $P$, Jindal $M$. Treatment of furcation involvement using autogenous tooth graft with 1-year follow-up: a case series. Clin Adv Periodontics. 2019; 9: 4-8.

70. Kim YK, Lee J, Kim KW, Um IW, Murata M, Ito K. Analysis of organic components and osteoinductivity in autogenous tooth bone graft material. J Korean Assoc Maxillofac Plast Reconstr Surg 2013; 35: 353-9.

71. Bessho K, Tagawa T, Murata M. Purification of rabbit bone morphogenetic protein derived from bone, dentin, and wound tissue after tooth extraction. J Oral Maxillofac Surg 1990; 48: 162-9.

72. Calvo-Guirado JL, Maté-Sánchez de Val JE, RamosOltra ML, Pérez-Albacete Martínez C, RamírezFernández MP, Maiquez-Gosálvez M, Gehrke SA, Fernández-Domínguez M, Romanos GE, DelgadoRuiz RA. The use of tooth particles as a biomaterial in post-extraction sockets. Experimental study in dogs. Dent J 2018; 6: 12.

73. Kim SK, Kim SW, Kim KW. Effect on bone formation of the autogenous tooth graft in the treatment of peri-implant vertical bone defects in the minipigs. Maxillofac Plast Reconstr Surg 2015; 37: 2.

74. Lee DH, Yang KY, Lee JK. Porcine study on the efficacy of autogenous tooth bone in the maxillary sinus. J Korean Assoc Oral Maxillofac Surg 2013; 39: $120-6$.

75. Kim YK, Kim SG, Um IW, Kim KW. Bone grafts using autogenous tooth blocks: A case series. Implant Dent 2013; 22: 584-9.

76. Lee JY, Kim YK, Yi YJ, Choi JH. Clinical evaluation of ridge augmentation using autogenous tooth bone graft material: case series study. J Korean Assoc Oral Maxillofac Surg 2013; 39: 156-60.

77. Pohl V, Pohl S, Sulzbacher I, Fuerhauser R, Mailath-Pokorny G, Haas R. Alveolar ridge augmentation using dystopic autogenous tooth: 2 year results of an open prospective study. Int J Oral Maxillofac Implants 2017; 32: 870-9.
78. Parvini P, Sader R, Sahin D, Becker J, Schwarz F. Radiographic outcomes following lateral alveolar ridge augmentation using autogenous tooth roots. Int J Implant Dent 2018; 4: 31.

79. Del Canto-Díaz A, De Elío-Oliveros J, Del CantoDíaz M, Alobera-Gracia MA, Del Canto-Pingarrón M, Martínez-González JM. Use of autologous toothderived graft material in the post-extraction dental socket. Pilot study. Med Oral Patol Oral Cir Bucal 2019; 24: 53-60.

80. Kim YK, Yun PY, Um IW, Lee HJ, Yi YJ, Bae JH, Lee $\mathrm{J}$. Alveolar ridge preservation of an extraction socket using autogenous tooth bone graft material for implant site development: prospective case series. J Adv Prosthodont 2014; 6: 521-7.

81. Kim YK, Lee J, Yun JY, Yun PY, Um IW. Comparison of autogenous tooth bone graft and synthetic bone graft materials used for bone resorption around implants after crestal approach sinus lifting: a retrospective study. J Periodontal Implant Sci 2014; 44: 216-21.

82. Pang KM, Um IW, Kim YK, Woo JM, Kim SM, Lee $\mathrm{JH}$. Autogenous demineralized dentin matrix from extracted tooth for the augmentation of alveolar bone defect: a prospective randomized clinical trial in comparison with anorganic bovine bone. Clin Oral Implant Res 2017; 28: 809-15.

\section{Sorumlu Yazarın Yazışma Adresi}

Öğr. Gör. Gözde IŞIK

Ege Üniversitesi Diş Hekimliği Fakültesi

Ağız, Diş ve Çene Cerrahisi AD

Bornova, İzmir, Türkiye

Tel no: 0232-311-28-09

E-Posta adresi: gozdech@hotmail.com 